\title{
Contrasting population dynamics and life histories in two populations of the colonial subtidal ascidian Podoclavella moluccensis
}

\author{
Andrew R. Davis* \\ Department of Zoology, University of Adelaide, GPO Box 498, Adelaide, SA 5001, Australia
}

\begin{abstract}
Population dynamics and aspects of life history of the colonial ascidian Podoclavella moluccensis Sluiter differed at 2 sites, a pier and a reef, within St Vincent's Gulf, South Australia. At Edithburgh Pier, colonies were dense and semelparous annuals. Densities at Port Noarlunga Reef were ca one-seventh of those at Edithburgh and this population was perennial and iteroparous. Population dynamics and fecundity of colonies also differed between sites. Fecundity was higher at Edithburgh, with a greater proportion of each colony brooding and having significantly larger broods. Recruitment at Edithburgh was an order of magnitude higher than at Port Noarlunga. This annual pulse of recruits at Edithburgh had a marked impact on size frequency distributions of colonies. Possible reasons for the observed variation in life histories within a species over small spatial scales $(60 \mathrm{~km})$ are discussed. The differences between sites identified in this study indicate that assessments of population dynamics and life history attributes of a species should not be restricted to a single site.
\end{abstract}

\section{INTRODUCTION}

Ascidians are distributed over wide geographic areas and are often remarkably abundant, even numerically dominant, in some communities (Millar 1971). Because this group is restricted largely to the sublittoral, observations of the dynamics of ascidian populations stem from, and are usually incidental to, investigations of the development and stability of epifaunal communities (e.g. Osman 1977, Sutherland \& Karlson 1977, Sutherland 1981, Russ 1980, Kay \& Butler 1983; but see Svane 1983, 1984, Svane \& Lundalv 1981, 1982a, b, Stocker \& Bergquist 1986).

Although many of these authors have recorded population densities of ascidians and the magnitude of change in density over time, few have identified the demographic processes producing these changes. In addition, most workers have introduced potential biases into their investigations by examining small areas of substratum, submerged for only short periods (usually less than $4 \mathrm{yr}$ ).

The size and age of substrata have an important influence on the species that settle on them and, in

\footnotetext{
- Present address: Harbor Branch Oceanographic Institution,
} 5600 Old Dixie Highway, Fort Pierce, Florida 33450, USA turn, the community that develops. Small substrata submerged for short periods will tend to be dominated by short-lived species heavily reliant on larval recruitment. They are, therefore, unlikely to be representative of epifaunal communities and their component species (Kay \& Keough 1981, Keough 1984).

The modular construction of colonial ascidians offers life history options which are not available to solitary organisms. Zooids (the repeated, physiologıcally connected units of these animals), or more commonly groups of zooids, are often capable of operating independently of the parent colony, even after separation from it. These physiologically independent sub-units of colonies, referred to as ramets by plant ecologists (Harper 1977), collectively represent one genotype, a genet. Colonies may split and separate by fission, but they also may join by fusion. Compatible ramets, usually derived from a single genet, may coalesce or fuse (Hughes \& Jackson 1980, Heyward \& Stoddart 1985).

Assessment of population size will be hampered if colony fission and fusion occurs regularly and rapidly (Bak et al. 1981). These processes also decouple the relationship between colony size and age. As a direct result, concepts of demography derived from solitary animals, such as age at first reproduction, are not applicable (Hughes \& Jackson 1985). 
Clearly, the study of population dynamics in colonial organisms will be confused if the products of colony fission and fusion cannot be distinguished from those of settlement of larvae and mortality of colonies. The degree of confusion will depend on the organisms studied and the intensity of sampling. In colonial organisms possessing a mineralized skeleton, such as corals, traces of their fission and fusion remain and annual sampling may be sufficient to distinguish these patterns (Hughes \& Jackson 1985). In contrast, softbodied organisms require more regular sampling if these patterns are not to be confused (Bak et al. 1981). In extreme cases, such as that observed by Ryland et al. (1984), observations every few hours may be necessary.

In this paper I examine the population dynamics of the colonial, subtidal ascidian Podoclavella moluccensis Sluiter (Polycitoridae; Aplousobranchia), a common and conspicuous member of the epifaunal community in the Gulf waters of South Australia. Colonies are sessile and attach to rocky reefs and artificial substrata, such as pier pilings. The aims of this study were to: (1.) examine the temporal changes in abundance of 2 populations of $P$. moluccensis; (2) investigate the demographic processes likely to produce these changes. These processes include: production and recruitment of sextally produced propagules, fission, fusion and mortality. All sampling was replicated and restricted to large substrata submerged for periods in excess of $20 \mathrm{yr}$

I follow Jackson's (1985) definitions and consider colonies that are physically separate, and therefore countable, to be individuals irrespective of whether they belong to different genets. The implications of this oversimplification will be discussed later. Reproduction will be considered a means by which the number of individual colonies is increased. Reproduction may be sexual, through the production of larvae and their subsequent settlement, or asexual, by the fission of a colony into separate entities.

\section{MATERIALS AND METHODS}

Study sites. Sampling was done at 2 sites in the Gulf of St Vincent, South Australia: Port Noarlunga Reef and Edithburgh Pier (Fig. 1). Port Noarlunga Reef $\left(35^{\circ} 09^{\prime} \mathrm{S}, 138^{\circ} 29^{\prime} \mathrm{E}\right)$ is a consolidated Pleistocene sand dune. This reef runs parallel to the coast, ca $350 \mathrm{~m}$ offshore, and is partially exposed at low tides. The inner (sheltered) side of the reef drops almost vertically to sand at around $7 \mathrm{~m}$ depth (MLLW). A dense forest of the laminarian Ecklonia radiata (C. Ag.) J Ag., and fucoid algae Sargassum spp., dominated sunlit rock surfaces, while the undersides of overhangs and vertical rock faces were dominated by a number of species

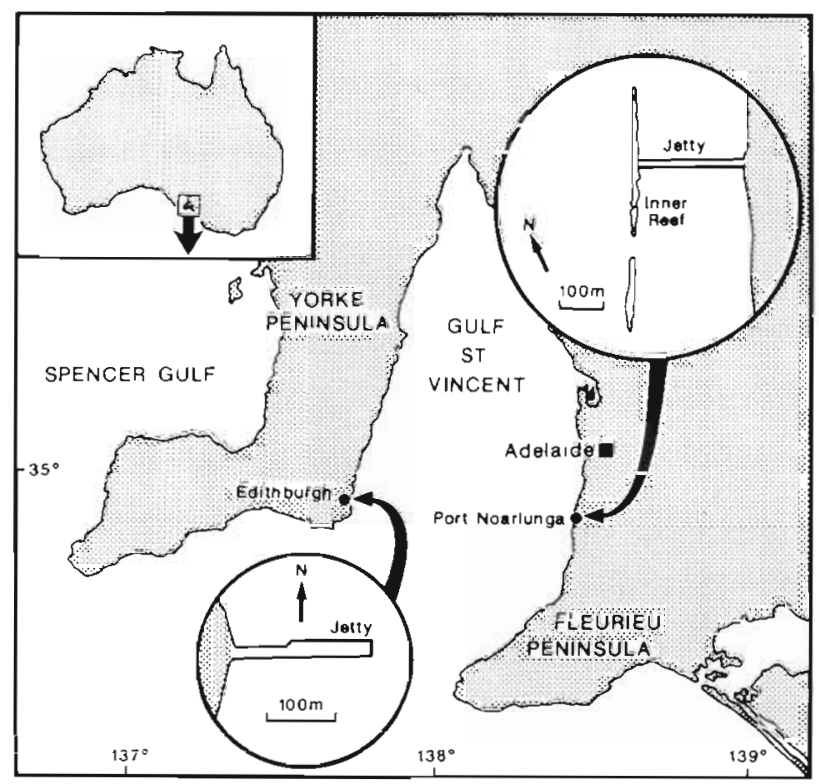

Fig. 1. South Australian Gulf waters with study sites labelled. Upper circular inset: Port Noarlunga Pier and reef: lower circular inset: Edithburgh Pier

of sponge and ascidian. The solitary ascidian Pyura irregularis (Herdman) reached densities of several hundred per $\mathrm{m}^{2}$

Edithburgh Pier $\left(35^{\circ} 05^{\prime} \mathrm{S}, 137^{\circ} 45^{\prime} \mathrm{E}\right)$ is sheltered from the prevailing southwesterly winds. The outer half of this wooden structure stands in ca $6 \mathrm{~m}$ of water (MLLW) and is flanked on 3 sides by seagrass meadows of Posidonia australis var. angusta Hook. Fauna common in the meadows and underneath the pier include the bivalve mollusc Pinna bicolor Gmelin and the solitary ascidians Phallusia obesa (Herdman) and Polycarpa viridis Herdman. The pier pilings themselves are dominated by sponges. A number of species of bryozoan and ascidian, in addition to the stony coral Culicia tenella Dana, were common also. This community is described in Kay \& Keough (1981) and Kay \& Butler (1983).

At both sites, seawater temperature varied between $23^{\circ} \mathrm{C}$ in summer (January and February) and ca $10^{\circ} \mathrm{C}$ in winter (July and August).

Estimating size of colonies. The size of colonial organisms has been estimated in 2 ways. Colony area has been measured (e.g. Hughes \& Jackson 1985) or the number of repeated units within a colony counted (e.g. KarIson 1983). Measurements of colony area are advantageous, as they are indicative of an organism's ability to obtain and hold space, potentially a limiting resource in epifaunal communities. However, such measurements of area are often difficult to obtain and, unless the organism grows as a thin sheet, may also be inaccurate. Counts of zooids reflect the population 
dynamics of a modular organism more directly, and this proved to be the most convenient means of estimating colony size for Podoclavella moluccensis. To ensure that counts of zooids were a good predictor of colony size (dry weight) and the area of substratum occupied by a colony, the relationship between these 3 measurements was investigated.

A sample of 56 colonies, representing the size range available, was collected from Edithburgh Pier in winter 1983. Zooids were removed from the stoloniferous basal 'mat' of a colony with a razor blade and placed in a plastic bag. The outline of this basal mat was traced onto an acetate sheet with a chinagraph pencil, then the mat was prised from the piling and placed in the plastic bag. All colonies were assigned numbers and kept in separate plastic bags.

In the laboratory, colonies were removed from the bags, the zooids were counted, and dry weights were determined after drying for $48 \mathrm{~h}$ at $50^{\circ} \mathrm{C}$. The area of attachment of each colony was calculated with a microcomputer by tracing the area of the basal mat on a digitizing pad. The regression of zooid number on the area of attachment and colony dry-weight was then calculated. I used model I regression analysis because of the present uncertainty surrounding the application of model II regression (Sokal \& Rohlf 1981, p. 555).

Temporal patterns. Monitoring was done at monthly intervals at Port Noarlunga and 6 wk intervals at Edithburgh Pier beginning in late 1983 and continued for over 2 yr. Photographs were taken and counts made in permanently marked quadrats measuring $0.17 \mathrm{~m}^{2}$ $(30 \times 56 \mathrm{~cm})$ at each site; 20 quadrats at Edithburgh Pier and 17 at Port Noarlunga Reef. Quadrat size was determined by the area on a piling which could be photographed. Quadrats were delineated by a nail driven into the top left hand corner. Ramset concrete nails were used at the reef site and were fixed in place with an epoxy putty (Expocrete). Relocation of quadrats was facilitated by the attachment of a short strand of Nichrome wire to the nails. At Edithburgh Pier a galvanized clout was driven through a small plastic or antifouling-coated steel plate to mark the quadrats. A strand of Nichrome wire was attached also

Quadrats were photographed with a Nikonos III camera and electronic flash. The camera was mounted in a frame which ensured that quadrats were framed accurately and that a distance from subject to camera of $0.8 \mathrm{~m}$ was maintained.

In addition to photographic sampling, changes in size frequency distribution of colonies and survivorship were assessed at Edithburgh Pier. At each sampling date the sizes of 200 colonies were estimated. On 10 randomly chosen pilings, the number of zooids were counted in 20 haphazardly selected colonies.

Estimates of survivorship were obtained at Edith- burgh by monitoring 90 permanently marked colonies in 1983 and 10 colonies in 1984. Colonies were marked by nailing a numbered 'Dymo' tag next to a colony and attaching a short strand of Nichrome wire to aid in relocation. In 1985, survivorship of 22 colonies was obtained from photographs of permanent quadrats. The presence of colonies was assessed at roughly 6 wk intervals in 1983 and 1984, and on 3 occasions during 1985.

At Port Noarlunga, colony size frequency and survivorship information was obtained by photographing permanent quadrats. Some data (e.g. recruitment) proved difficult to obtain from these photographs and quadrats were then assessed visually as well.

Reproductive status. The larvae of Podoclavella moluccensis are retained in a conspicuous brood pouch in the peribranchial cavity. Larvae are subsequently released at an advanced stage of development. To determine the number of larvae produced by $P$. moluccensis at each site, 3 variates were examined: the frequency of sexual reproduction, the number of zooids brooding, and the number of larvae per brood.

To determine how often Podoclavella moluccensis reproduced, the reproductive status of adult colonies was determined by destructive sampling at Edithburgh Pier. Ten colonies were marked with numbered 'Dymo' tags and Nichrome wire, as described earlier. At ca 6 wh intervals samples of 5 zooids were removed from each colony, preserved in formalin, and examined in the laboratory. Samples with obvious gonads were sectioned at a thickness of 7 um, stained (Ehrlich's Haematoxylin und Eosin) and examined under a microscope at $20 \times$ to confirm the presence of sperm and ova within the gonads. The assessment of reproductive status at Port Noarlunga was restricted to the examination of zooids for the presence of gonads in the field.

The number of zooids brooding and the number of larvae per brood were estimated by sampling at both sites in 1985 and 1986. The number of zooids possessing brood pouches was determined by counting the total number of zooids in 10 to 14 colonies on each sampling date and recording the presence or absence of a brood pouch on each zooid. Brood pouches were blue and were usually counted easily in the field without destruction of colonies. The presence of larvae within the pouch was not determined.

Determination of the number of larvae per pouch required destructive sampling and were made only once at each site in each year. Zooids from brooding colonies were removed to the laboratory. The heights of these zooids were measured, they were dissected and the number of larvae per pouch was counted. Between 5 and 10 zooids were removed from each colony.

Differences in the number of brood pouches per 
Table 1. Podoclavella moluccensis. Percentage of colonies undergoing fission and mean number of daughter colonies produced per fission event at Port Noarlunga Reef and Edithburgh Pier

\begin{tabular}{|c|c|c|c|c|c|c|}
\hline \multirow[t]{2}{*}{ Site } & \multirow[t]{2}{*}{ Year } & \multicolumn{2}{|c|}{$\%$ of colonies undergoing fission } & \multicolumn{3}{|c|}{ No of daughter colonies produced per fission } \\
\hline & & $\%$ & $n$ & Mean & $95 \%$ CI & $n$ \\
\hline \multirow[t]{2}{*}{ Edithburgh Pier } & 1983 & 4.5 & 66 & \multirow[t]{2}{*}{2.3} & \multirow[t]{2}{*}{0.4} & \multirow[t]{2}{*}{9} \\
\hline & 1984 & 7.6 & 79 & & & \\
\hline Port Noarlunga Reef & $1984+1985$ & 39.0 & 33 & 4.7 & 1.5 & 13 \\
\hline
\end{tabular}

colony and number of larvae per brood between sites and years were examined with a 2 -factor ANCOVA The factors, each with 2 levels, were site and year. Estimates of brood number are likely to be influenced by the size of the colonies, while zooid height may influence the number of larvae per brood. Both of these variables were included in the analyses as covariates. Several assumptions are made by ANCOVA (Huitema 1980). One of the most important of these is that the regression slopes for the groups are not significantly different. Equality of regression slopes and any heterogeneity among variances were tested before proceeding with the 2 -factor analyses.

If the sizes of larvae do not vary significantly between sites, then the total number of larvae per colony equates to reproductive effort. In 1985, a sample of larvae were dissected from brood pouches collected at each site and their sizes (maximum trunk diameter) were measured with a graticule at $20 \times$

\section{RESULTS}

\section{Zooid number, colony biomass and area of attachment}

The number of zooids in a colony showed a significant relationship with colony biomass (dry weight) (Zooid number $=24.15+[69.5 \times$ colony dry weight $], r^{2}$ $=0.89, t=21.4, p<0.001, \mathrm{df}=54$ ), and a significant relationship with the area of substratum occupied by a colony (Zooid number $=1.25+[0.11 \times$ area of attachment], $r^{2}=0.75, t=12.5, p<0.001, \mathrm{df}=51$ ). In both relationships the best fit of the data to the model, as judged by $r^{2}$ values, was obtained with the raw data.

\section{Sexual reproduction}

Reproduction of colonies was predominantly sexual at both sites. Podoclayella moluccensis was hermaphroditic and gonads became apparent within the gut loop of colonies in early to mid August. Histology revealed that by early September some colonies had functional gonads and were producing sperm and ova simultaneously. In late September and early October, brood pouches developed at the base of the branchial basket. Blue in colour, these pouches were very conspicuous particularly when distended with developing larvae. Larvae were released from late October through early December at both sites. Larvae were $4 \mathrm{~mm}$ in length and possessed a blue pigment spot that made them highly conspicuous.

\section{Asexual reproduction}

Colony fission occurred at both sites, although at very different frequencies. At Edithburgh Pier, only $4.5 \%$ of the colonies $(n=66)$ were observed to undergo fission in 1983 and $7.6 \%(n=79)$ in 1984. At Port Noarlunga, $39 \%$ of the colonies observed $(n=33)$ underwent fission. The number of daughter colonies produced in one fission event was also significantly larger at Port Noarlunga (Table 1).

At both sites, daughter colonies were usually small, rarely exceeding 10 zooids in size, and were never found to be separated from the parent colony by more than a few centimetres. The probability of these colonies surviving for more than 3 to 4 mo was low (Fig. 2).

Colony fusion was not observed, even among ramets of a single genet.

\section{Formation of daughter colonies}

Fission was intimately linked with the degeneration of colonies. Colonies at each site went through a phase of colony degeneration, followed by rapid regeneration. At both sites fission was preceded by colony degeneration $(n=22)$ with only one exception. It appeared that some stolons within the basal mat were damaged, or 'atrophied', during the degeneration process, resulting in the production of one or more daughter colonies.

Degeneration was characterized by closure of siphons and the shrinkage of a zooid within its test. Ultimately this shrinkage produced a small whitish nodule on the blue stoloniferous basal mat, measuring 2 to $3 \mathrm{~mm}$ in height. A flaccid piece of test remained after shrinkage of the zooid. This was usually dislodged 


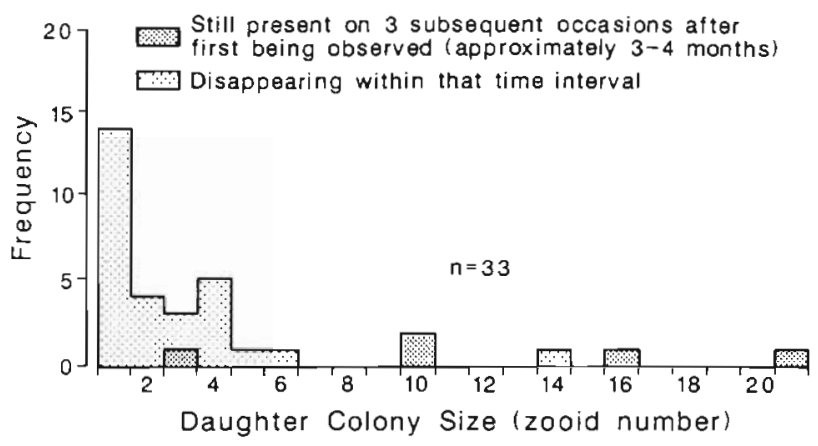

Fig. 2. Podoclavella moluccensis. Size frequency distribution of daughter colonies when first formed, at Port Noarlunga $(n=33)$

by wave action, and the nodule regenerated into a functional zooid. The whole process usually took less than 1 mo to complete.

Sometimes zooid degeneration within a colony was synchronous, while on other occasions, only a proportion of the colony would degenerate leaving some functional zooids. The degeneration of these functional zooids occurred a short time later.

Colony degeneration occurred at different rates at the 2 sites, hence the rate of formation of daughter colonies differed also. At Edithburgh Pier, degeneration occurred during the winter months of May and June and then later, following the appearance of recruits in October and November (Fig. 3). At this site then, the majority of colonies degenerated twice, although occasionally colonies degenerated twice during winter and then once again during late spring (Fig. 4). Degeneration in November and December was rarely followed by regeneration; it often resulted in colony fission and was almost invariably followed by the death of colonies.

Degeneration was not periodic at Port Noarlunga, occurring year-round and with a higher frequency than seen at Edithburgh (Fig. 3). Colonies at this site degenerated and subsequently regenerated between 3 and 9

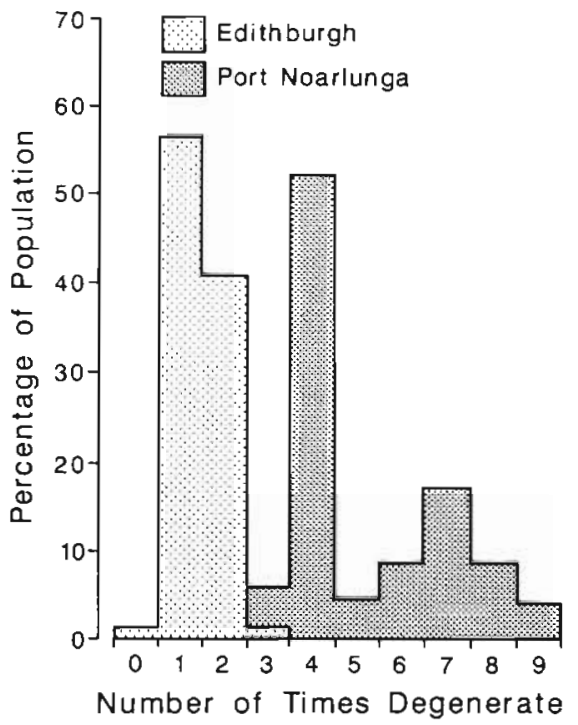

Fig. 4. Podoclavella moluccensis. Frequency distribution (expressed as percentage of the population) of the number of times colonies were observed to degenerate at each site. Frequencies are for the lifetime of colonies at Edithburgh and only a portion of the lifetime of a colony at Port Noarlunga. Frequencies are based on 76 observations at Edithburgh Jetty and 23 at Port Noarlunga. Colonies not followed for at least 4 mo have been omitted

times over 2 yr of monitoring (Fig. 4). Records of degenerate colonies are likely to be underestimates due to the frequency of monitoring. Daughter colonies were produced throughout the year with a larger number of daughter colonies produced, on average, per fission event than at Edithburgh (Table 1). Degeneration on this reef seldom culminated in colony death.

\section{Population dynamics}

The population of Podoclavella moluccensis at Edithburgh Pier maintained a higher density than that at

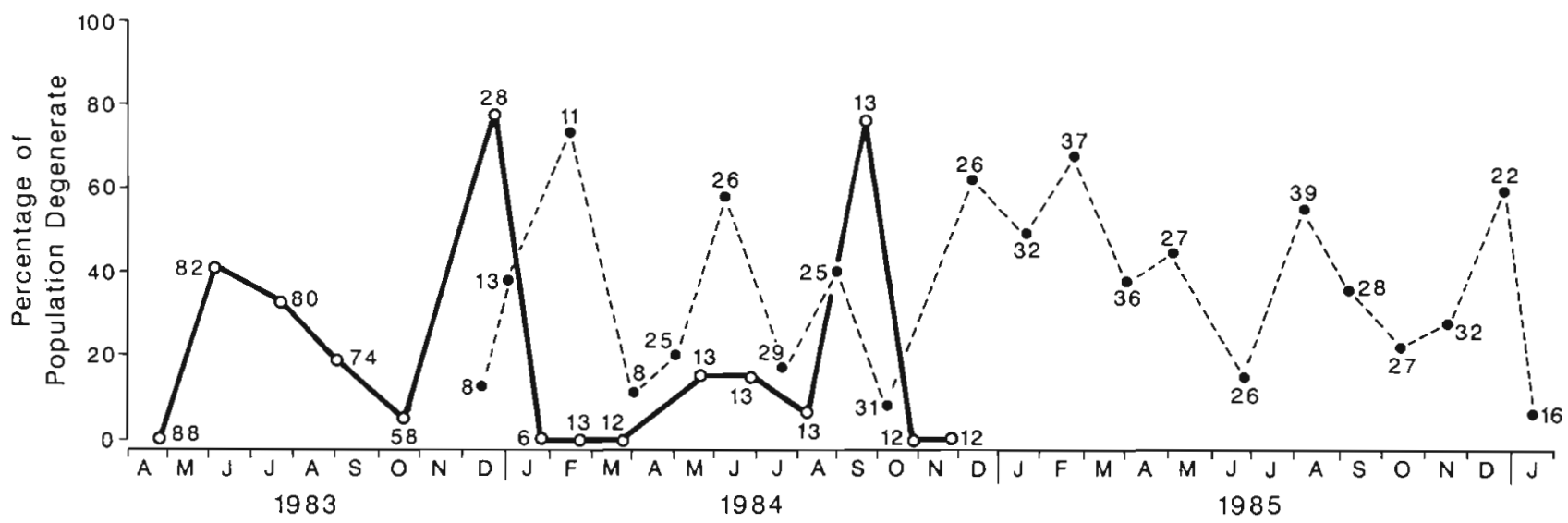

Fig. 3. Podoclavella moluccensis. Percentage of population that was degenerate at each site over time. Solid line: Edithburgh; broken line: Port Noarlunga. Sample sizes indicated at data points 
Port Noarlunga, but showed marked fluctuations in density with time (Fig. 5). Intense recruitment accounted for the increase in density observed in late spring (November and December) of 1984 and 1985. This pulse of recruits was also observed in spring 1983 , but was not measured.

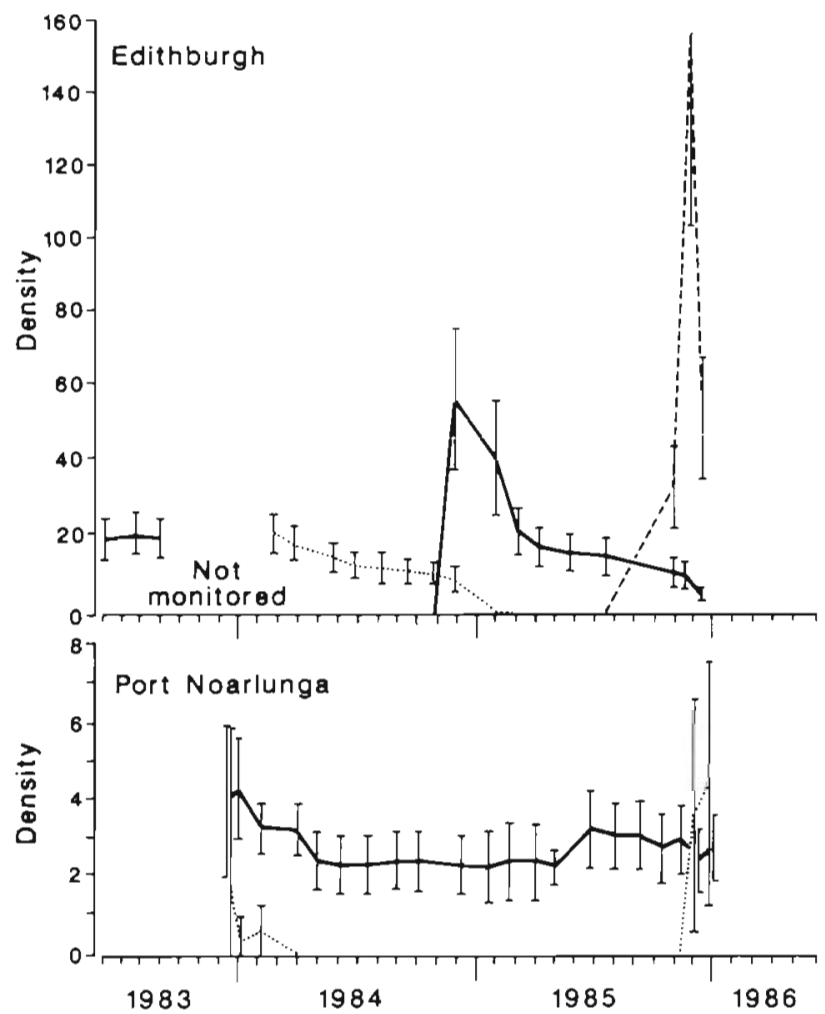

Fig. 5. Podoclavella moluccensis. Changes in density with time at Edithburgh Pier and Port Noarlunga Reef. Means are number of colonies per $0.17 \mathrm{~m}^{2}$, irrespective of whether they represent ramets or genets. Error bars are $95 \%$ confidence intervals. At each site, the density of each new cohort is represented by a separate line. Note that recruitment was not quantified although it did occur at Edithburgh in November 1983 and at Port Noarlunga in November 1984. Also note the different scales on the $\mathrm{Y}$ axes

Recruitment was followed by a steady decline in numbers through the year, the last colonies dying in December, or January and February of the following year (Fig. 6). The mortality of mature colonies and the influx of large numbers of recruits markedly reduced mean colony size in late spring and early summer. Growth produced a shift toward larger colonies in the following months (Fig. 7)

Colonies were less dense at Port Noarlunga, but densities remained far more constant than in the Edithburgh population, during the $2 \mathrm{yr}$ of monitoring (Fig. 5).

Much of the variation in colony density observed at Port Noarlunga can be attributed to changes in the

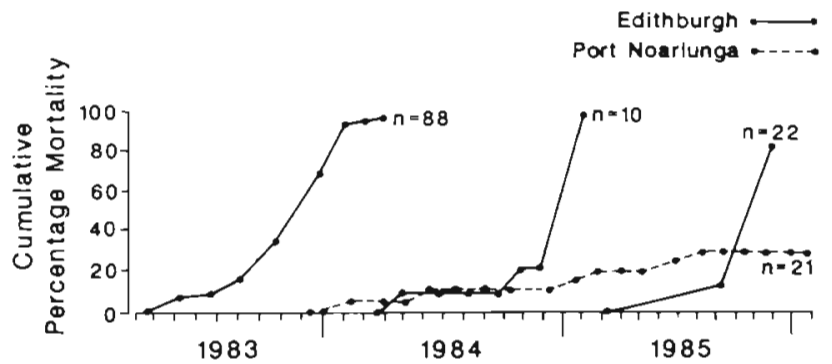

Fig. 6. Podoclavella moluccensis. Cumulative percentage mortality of colonies at each site. Only mortality of marked colonies is considered, hence mortality of recruits has been omitted

number of quadrats monitored, rather than real changes in number. When sampling was initiated, only a small number of quadrats were monitored, with considerable variation apparent in the density estimates obtained (Fig. 5). This was rectified in March 1984 with the marking and photographing of 17 quadrats. By May 1985 it was apparent that results from only a subsample of these quadrats could be reliably interpreted from the photographs. The quadrats most difficult to interpret were those containing the most colonies. Beginning in July 1985, visual censuses of all quadrats were made in addition to photographic monitoring. This allowed the inclusion in the data of particular quadrats that previously had been difficult to monitor photographically, thereby raising the estimated densities.

Pulses of recruitment occurred at Port Noarlunga in all years, but the poor resolution of photographic monitoring rendered estimates of recruitment unreliable. Visual censusing of all quadrats produced reliable estimates of recruitment in the spring of 1985. Although these pulses were synchronized with those seen at Edithburgh, they were of much lower magnitude. In addition, most recruits soon died.

The relatively low rates of recruitment at Port Noarlunga, and the frequent production of small daughter colonies, produced a colony size frequency distribution that was very different from that seen at Edithburgh. Colony sizes were relatively small year-round, rather than during just the settlement season (Fig. 8).

At Port Noarlunga, ramets from a single genet could usually be easily distinguished by their small size and close proximity to the parent colony. At this site, genet rather than ramet mortality was considered. Genets were long-lived at Port Noarlunga. In more than $2 \mathrm{yr}$ only 6 of the 21 permanently marked genets (28.5\%) disappeared (Fig. 6), despite a severe storm in March 1983. Casual observations at this site indicate that the longevity of some Podoclavella moluccensis genets is greater than $4 \mathrm{yr}$. 


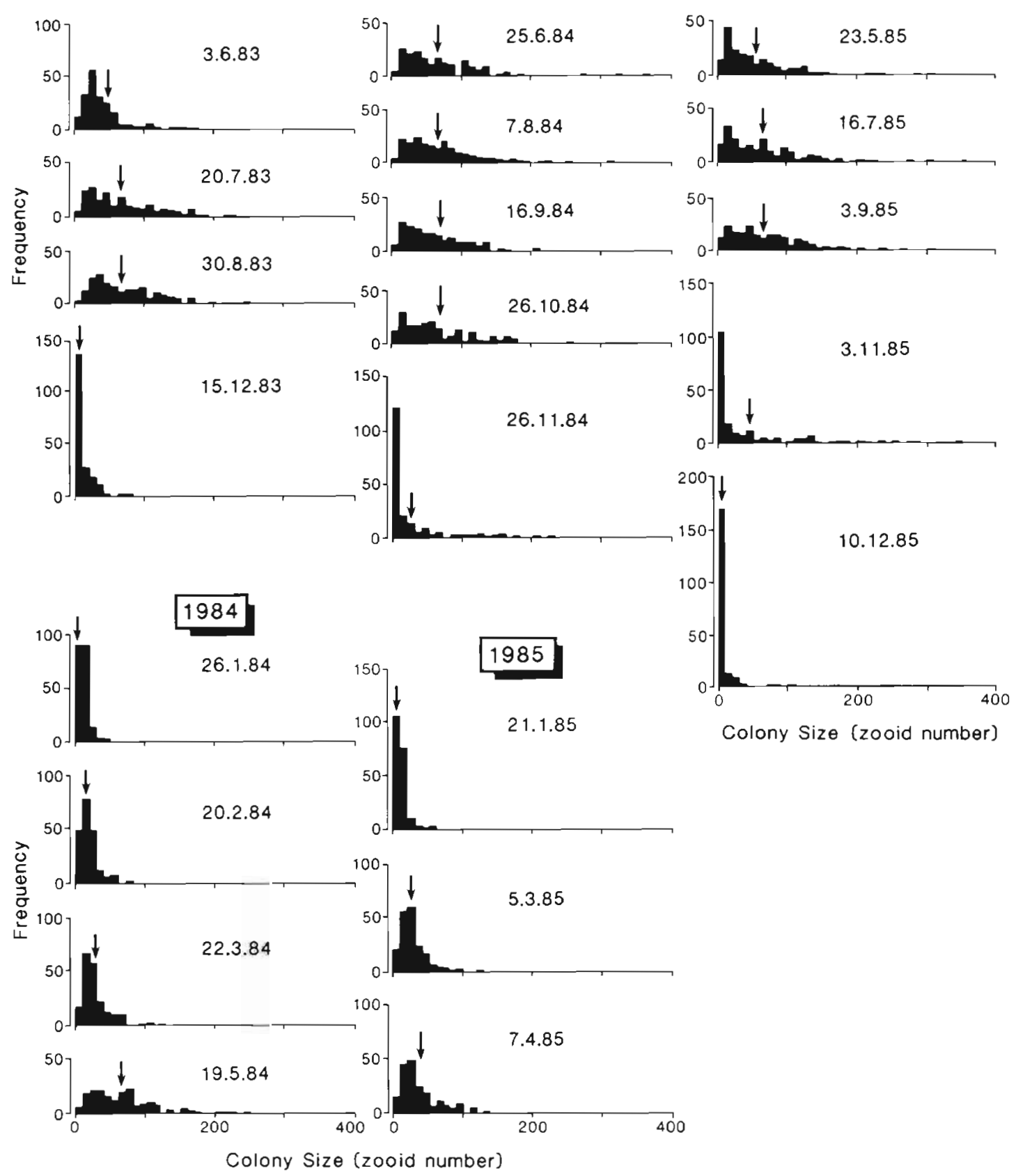

Fig. 7. Podoclavella moluccensis. Size frequency distribution of colonies (zooid number) at Edithburgh Pier. Arrows represent mean size

\section{Comparison of number of larvae produced at each site}

Colonies at both sites reproduced sexually during late spring, November to early December. Significant differences were observed in the number of brood pouches per colony and the number of larvae in each brood pouch at the 2 sites. No significant differences in the size of larvae were detected.
Brood pouches per colony

The number of zooids per colony with brood pouches was divided by the total number of zooids, yielding the proportion of each colony brooding. On average, more than half of each colony at Edithburgh was brooding in 1985 and 1986 (Fig. 9). In contrast, the mean proportion brooding at Port Noarlunga in 1985 was less than 0.1 . 

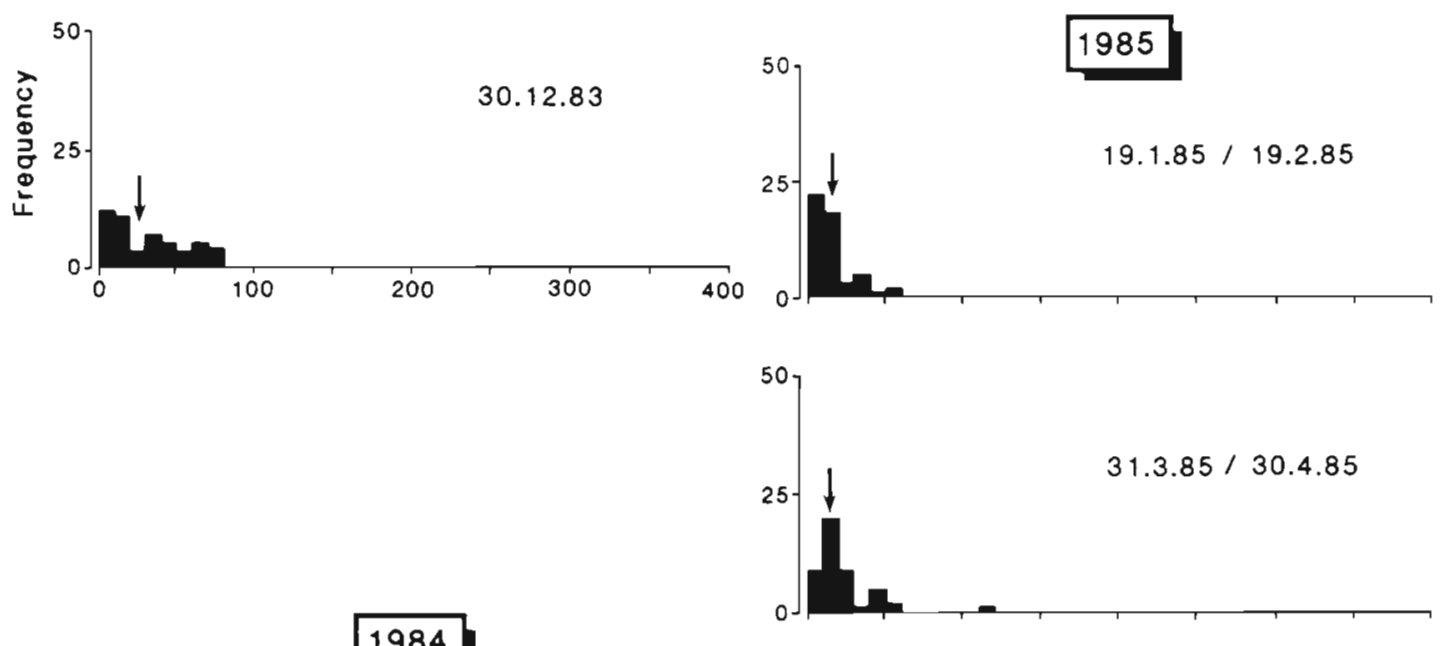

1984
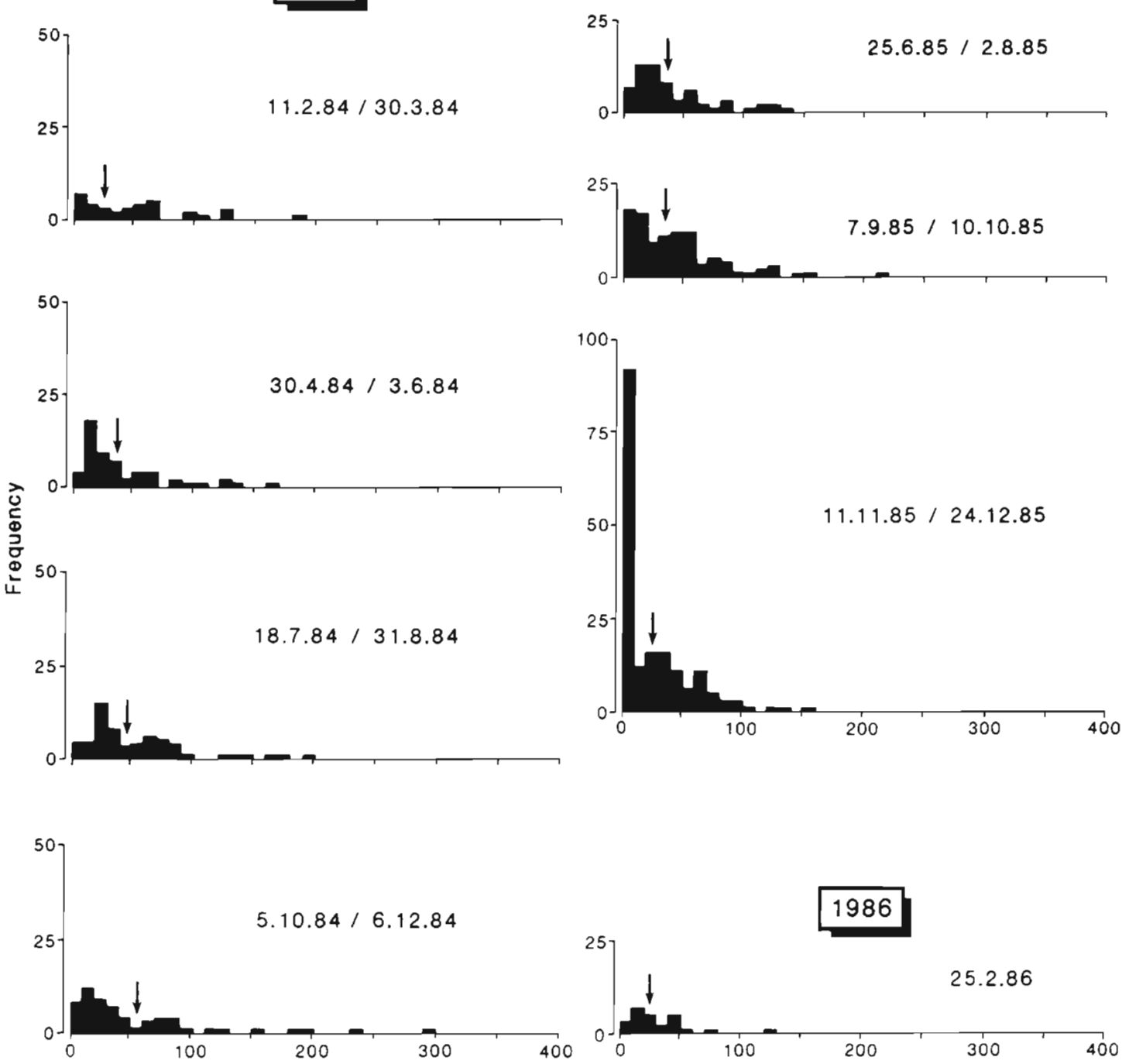

Colony Size (zooid number)

Fig. 8. Podoclavella moluccensis. Size frequency distribution of colonies (zooid number) at Port Noarlunga Reef. Arrows represent mean size. Two dates separated by a slash indicate that samples from these dates have been pooled 


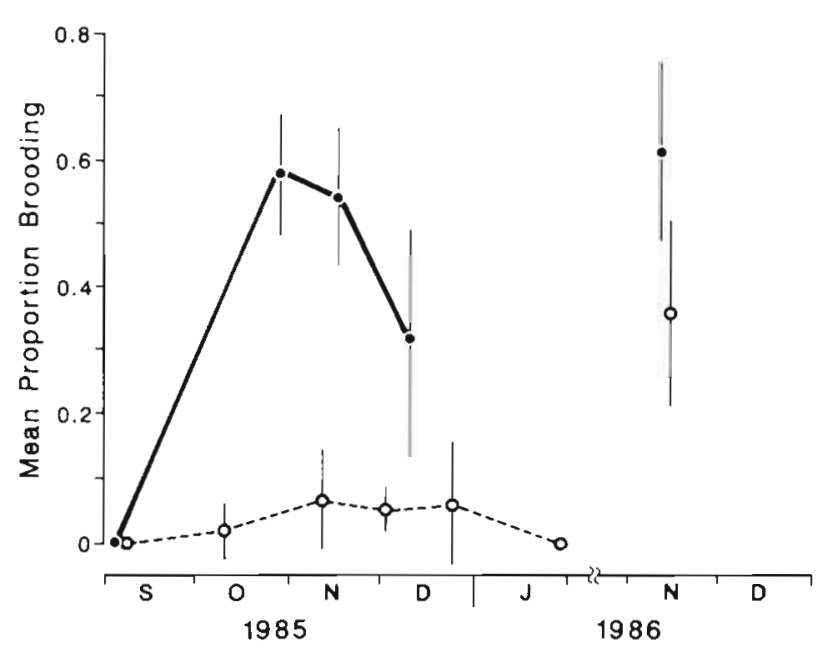

Fig. 9. Podoclavella moluccensis. Mean proportion of a colony possessing brood pouches at the 2 sites. Means were calculated from counting all zooids within 10 to 14 colonies on each date. Error bars are $95 \%$ confidence intervals. Solid line: Edithburgh; broken line: Port Noarlunga

In 1986, however, this figure rose to almost 0.4 , and considerable variability was apparent in the proportion brooding. Indeed, one colony at Port Noarlunga in 1986 had the highest proportion of brood pouches observed: 0.96 of the zooids in that colony possessed brood pouches.

The proportion of each colony with brood pouches was analysed with a 2-factor ANCOVA; data were arcsine transformed prior to analysis. Zero proportions were replaced with the term $1 / 4 n$ (Snedecor \& Cochran 1980, p. 290). A test for the equality of regression slopes
(Engleman 1985) revealed no significant differences between groups $(F=0.29 \mathrm{df}=3.88 p>0.5)$. Although the sample sizes between year were unequal (1985, $n=36 ; 1986, n=12$ ), they are proportional and the analysis is therefore orthogonal (Huitema 1980, p. 198). The ANCOVA revealed significant differences between sites and years, and the covariate, colony size, was also highly significant; large colonies had higher proportions of zooids brooding. The interaction of site and year was not significant (Table 2). An examination of the marginal adjusted means (as there are only 2 levels for each factor of the ANCOVA, a multiple comparison test is not required, Huitema 1980) revealed that a significantly higher proportion of colonies were brooding at Edithburgh. In addition, a significantly higher proportion of colonies were brooding in 1986 than in 1985.

\section{Number of larvae in each pouch}

The brooding of larvae was correlated with zooid height. Zooids of less than $15 \mathrm{~mm}$ in height were rarely observed to brood larvae (Fig. 10). The ANCOVA of number of larvae in each brood pouch showed the same pattern as was observed in the number of brood pouches per colony (Table 3 ). The 2-factor ANCOVA revealed differences between sites and years, while the interaction term was non-significant. The covariate, zooid height, was also significant; larger zooids produced larger broods. The marginal adjusted means indicated that colonies at Edithburgh had larger broods and that broods in 1986 were larger than those in 1985.

Table 2. Podoclavella moluccensis. Analysis of the number of brood pouches per colony at Edithburgh Pier and Port Noarlunga Reef in 1985 and 1986. Data were analysed with a 2-factor ANCOVA. The factors were Site (fixed) and Year (fixed), each with 2 levels. Means were determined from the number of zooids with brood pouches divided by total number of zooids per colony. Zero proportions were converted to $1 / 4 n$ (Snedecor \& Cochran 1980) and the data were arcsine transformed prior to analysis. Cochrans's $C$ on transformed data $=0.38, k=4, \mathrm{df}=35, p>0.05$. Slopes not significantly different $(F=0.29, \mathrm{df}=3,88, p>0.05)$. The adjusted means and marginal adjusted means are untransformed

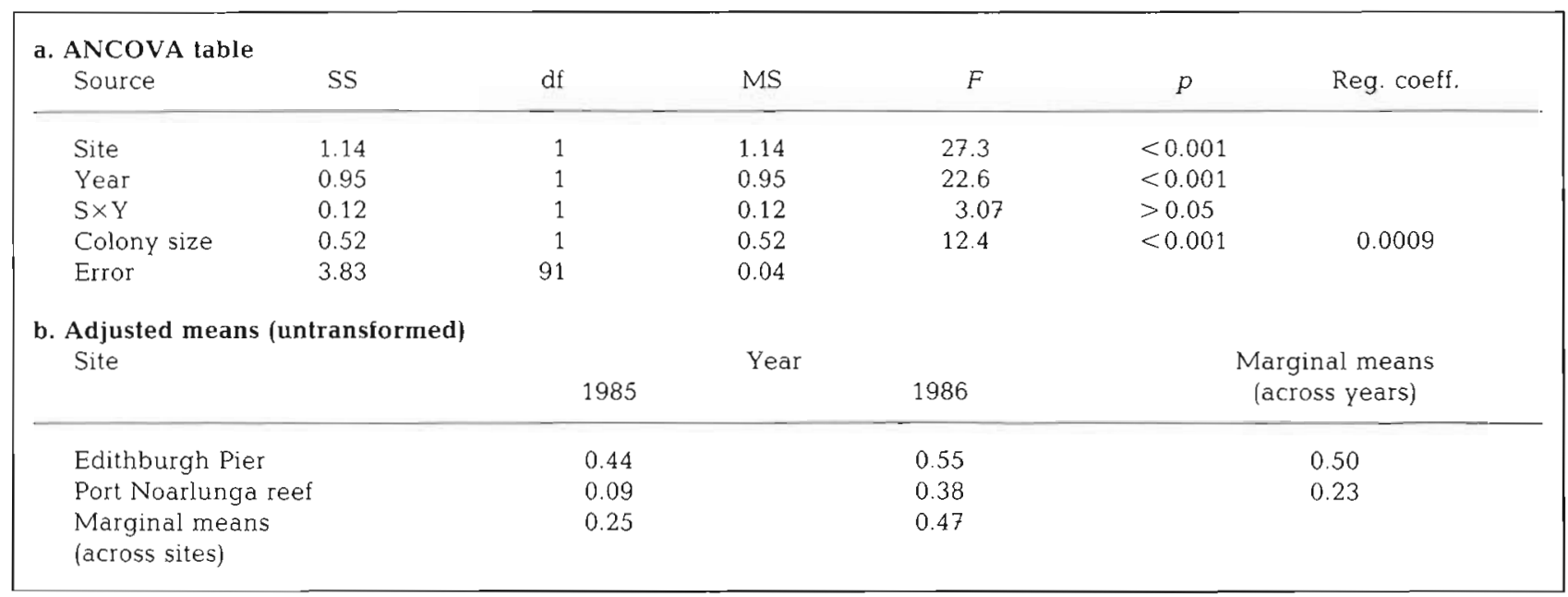


Table 3. Podoclavella moluccensis. Number of larvae per brood pouch in colonies from Edithburgh Pier and Port Noarlunga Reef in 1985 and 1986. Data were analysed with a 2-factor ANCOVA. Factors were Site (fixed) and Year (fixed), both with 2 levels. Prior to analysis, data were $\log$ transformed. Cochran's $C$ on transformed data $=0.29, k=4, \mathrm{df}=43, p>0.05$. Slopes not significantly different $(F=2.1, \mathrm{df}=3,168, p>0.05)$. The adjusted means and marginal adjusted means are untransformed

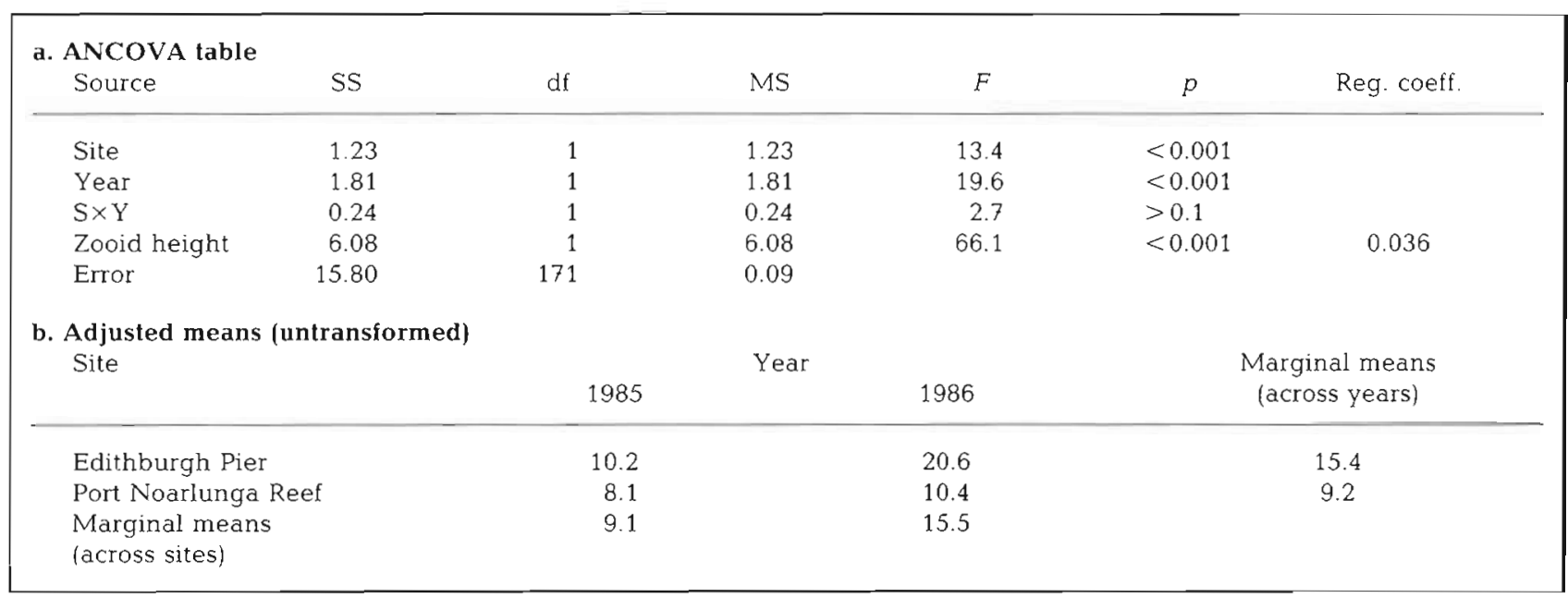

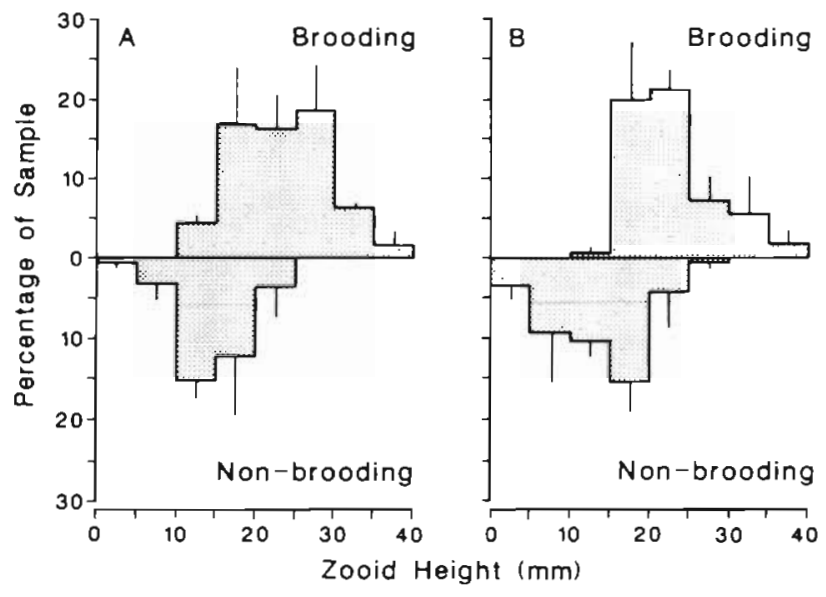

Fig. 10. Podoclavella moluccensis. Frequency of brooding and non-brooding zooids versus zooid height $(\mathrm{mm})$ at each site. Mean percentage of each sample ( \pm standard error) was calculated from 2 yr, 1985 and 1986. (A) Edithburgh; (B) Port Noarlunga

\section{Comparison of larval size}

The diameters of larvae in brood pouches were not significantly different between sites in $1985(t=1.34$ $\mathrm{df}=118, p>0.05)$. On average, brooded larvae at Edith. burgh measured $0.90 \mathrm{~mm}$ (SE $=0.03$ ), while at Port Noarlunga the average size was $0.86 \mathrm{~mm}(\mathrm{SE}=0.01)$.

\section{DISCUSSION}

Natural population often show considerable fluctuation in density over time. It was this variability in natural systems that led Charles Elton (1930) to reject the concept of 'the balance of nature' and since then other workers have highlighted the significance of variability (Andrewartha \& Birch 1954, 1984, den Boer 1968, Chesson 1978, 1985, Underwood 1981, May 1986).

Most natural populations can be considered to consist of a series of interconnected subpopulations occupying more-or-less discrete patches of suitable habitat. These subpopulations will fluctuate in density as a result of local conditions and variation in the dispersal between them. To understand the dynamics of populations requires detailed knowledge of the processes occurring within patches and those affecting exchange between patches. Here, I sought information on the former processes and I document marked fluctuations in density and contrasting life history attributes for populations of a single species separated by $60 \mathrm{~km}$ of gulf waters.

Fluctuations in density of Podoclavella moluccensis and colony size structure were markedly different between the 2 sites. At Port Noarlunga the pulses of recruits were small and few recruits were observed to become established. Hence recruitment had little impact on population density or colony size structure at this site. In contrast, colony density in the annual population at Edithburgh was maintained by a large annual pulse of recruits, resulting in large fluctuations in density and population size structure within years. Problems experienced in scoring recruitment from photographs of quadrats at Port Noarlunga produced gaps in the data set, but did not alter the conclusions of this study. Casual observations of recruitment into these quadrats prior to 1985 indicated that the timing 
and magnitude of recruitment conformed to the patterns observed in 1985 at this site

At both sites, fluctuations between years were small, even though colony densities at the 2 sites differed by 7 -fold. The longevity of colonies in the perenial population at Port Noarlunga was responsible for the near absence of fluctuations in population size. As the longevity in this population exceeded the period of my monitoring, the same individuals were being observed and only slight fluctuations would be expected (Frank 1968, Connell \& Sousa 1983). It has been argued that to assess realistically the magnitude of fluctuation in populations requires observations after a period in which a complete turnover of the population has occurred. That is, a period exceeding the maximum longevity of all members of the population (Connell \& Sousa 1983). Complete turnover of the population at Port Noarlunga may take several years, and without a longer-term data set, little can be said about fluctuations in population density at this site.

The near constancy in adult population size observed between years at Edithburgh was surprising. This annual population was wholly maintained by recruitment yet adult densities were highly consistent in the 3 yr of monitoring. The availability of suitable sites for the settlement of larvae and the short distance dispersed by the larvae of this species most likely account for the consistency in density at Edithburgh, in addition to maintaining the differences in density at Edithburgh and Port Noarlunga (Davis \& Butler unpubl.). Larval settlement is certainly an important determinant of adult distribution and abundance in this ascidian species (Davis 1988).

I initially considered physically separate groups of zooids to be colonies, irrespective of whether they belong to different genets. At Edithburgh, colony fission was almost invariably observed just prior to colony death. Hence, individual colonies are genets. At Port Noarlunga, however, a genet may comprise one or more colonies. At this site small colonies were often short-lived, whereas genets usually persisted for periods exceeding the $2 \mathrm{yr}$ of monitoring. Fortunately, ramets of a single genet could usually be distinguished by their small size and close proximity to the parent colony, otherwise the short-lived ramets would have confused the persistence of genets at this site.

Natality and mortality were important determinants of the population dynamics at the sites examined. Colony fission and fusion may also influence the dynamics of invertebrate populations with a modular construction. Indeed, fission and fusion may exert more influence on population density than the establishment of sexually produced larvae or mortality (Bak et al. 1981). Fission and fusion were not significant life history attributes in Podoclavella moluccensis. Fusion was not observed and fission occurred frequently only at one site, Port Noarlunga. Not only was fission relatively infrequent at Edithburgh, it was also inconsequential, usually occurring just prior to the death of colonies. At Port Noarlunga, the products of fission were usually small and short-lived. Very few survived to reproduce and the fecundity of these small colonies was low, as indicated by the significant covariate in the analysis of brood number (Table 2). High rates of mortality and low fecundity associated with the small size of daughter colonies have been observed in a range of invertebrate taxa (Highsmith 1982, Hughes \& Jackson 1985 , Karlson pers. comm.). However, these 'drawbacks' may be compensated for by faster growth rates of these small fragments (Hughes \& Jackson 1985, Connell pers. comm., Karlson pers. comm.), or enhanced feeding ability (McFadden 1986). High rates of mortality were observed in small fragments of $P$. moluccensis colonies; whether this was compensated for by faster rates of growth could not be assessed adequately because of an insufficient sample size.

For modular organisms in general, the production of daughter colonies by fission may spread the risk of genet mortality Fragmentation reduces the chance of an entire genet being killed by a localized event. Hughes \& Jackson (1985) documented highly localized mortality on a coral reef in which some coral genets had spread over $5 \mathrm{~m}$ through fission. Genets of ramose corals may spread over even larger distances owing to their habit of dispersing by fragmentation and subsequent regrowth (Tunnicliffe 1981, Highsmith 1982). In Podoclavella moluccensis however, colony fission spreads ramets over very small distances, seldom more than a few centimeters. Any event acting to remove a ramet and leave others intact would have to be extremely localized. But the spreading of risk need not be restricted to spatial scales, as risks may also be spread through time (den Boer 1968). For example, differences in the rate of maturation or the timing of birth may alter the probabilty of survival in a heterogeneous, fluctuating environment. The significance of colony fragmentation in $P$. moluccensis to the spreading of risk in time was not assessed.

Colony fission in Podoclavella moluccensis, with one exception, was almost always preceded by colony degeneration. Differences in the frequency and timing of colony degeneration at each site explained the differing rates of colony fission observed. Colony degeneration was frequent at Port Noarlunga, hence daughter colonies were produced year-round. At Edithburgh, degeneration was restricted to the winter and just after breeding in spring. Inexplicably, daughter colonies did not form in winter at this site: they were observed regularly only just prior to colony death in early summer. 
Different life histories were apparent between populations at Edithburgh Pier and Port Noarlunga Reef Casual observations of colonies on the pilings of Port Noarlunga Pier revealed that iteroparity was not restricted to colonies attached to the rocky reef. Semelparous and iteroparous life histories may arise as a result of differences in age specific mortality (Chamov \& Schaffer 1973). If adult survival is high relative to the survival of offspring then selection will favour an iteroparous life history. Conversely, should the offspring stand a better chance of survival than their parents then semelparity should be favoured. As expected, the semelparous population at Edithburgh has more broods per colony and they contain, on average, greater numbers of larvae than those produced by the iteroparous population at Port Noarlunga. These differences between semelparity and iteroparity raise 2 questions. First, do differences in adult or juvenile survival determine the life history tactics (sensu Stearns 1976) adopted by Podoclavella moluccensis and, second, are these life histories under genetic control, or are they environmentally induced?

Available evidence indicates that juvenile survival was enhanced at Edithburgh, while at Port Noarlunga adult survivorship was favoured. Juvenile Podoclavella moluccensis survive particularly well on bare space (Davis 1987). Bare space was common at Edithburgh Pier, representing around $25 \%$ of the cover of pilings (Kay \& Butler 1983). In constrast, bare space was not observed to exceed $1 \%$ at Port Noarlunga (Davis unpubl.). The dynamic environment of Edithburgh Pier, therefore, may not favour adult survivorship. In an assessment of stability at Edithburgh Pier, Kay \& Butler (1983) found around $50 \%$ of the space changed occupants at least once in the 2 or so years of monitoring. So, competition for space was intense at this site and the probability of overgrowth by neighbouring species was high. In contrast, casual assessment of photographs of permanent quadrats at Port Noarlunga Reef reveal this community to be far less dynamic. The relative stasis observed at Port Noarlunga can be attributed to the large number of long-lived solitary animals and may promote the survival of adult colonies of P. moluccensis.

An appropriate experiment to answer the second question is a reciprocal transplant. I attempted such an experiment but, although colonies were transferred successfully, within 3 mo storms at both sites had destroyed the experiment. A host of environmental mechanisms could have produced the life history differences observed between sites. For example, differences in the quality or quantity of sources of nutrition may account for the differences observed. Without detailed information about the environmental differences between these sites, it is difficult to distin- guish among alternatives. I propose one possible environmental mechanism which is consistent with the empirical data and could be tested: the availability of sperm, and in turn the number of ova fertilized, may determine whether a colony is semelparous or iteroparous. If sperm are 'readily available', as is the case when population density is high, then all ova produced by a colony may be fertilized and with insufficient energy remaining for somatic growth the colony will fail to regenerate after reproduction and die. If, however, the supply of sperm is 'limiting' any unfertilized eggs may be resorbed, as has been observed in Botryllus schlosseri (Goodbody 1961), and energy redirected into somatic growth in the following year. This model assumes that Podoclavella moluccensis is not self-fertile and predicts that populations at low density will be perennial and iteroparous. Interannual variation in the proportion of colonies brooding, as observed at Port Noarlunga, indicates that sperm availability or fertilization success may vary. It follows then, assuming the scenario I have outlined is correct, that iteroparous colonies which receive relatively large quantities of sperm may switch to a semelparous life history. In proposing this model, I do not mean to suggest that life history attributes are under the control of a single mechanism, although this is the most parsimonious alternative.

This paper has documented marked life history variation within an ascidian species, over less than $1^{\circ}$ of longitude $(60 \mathrm{~km})$. The between-site differences identified indicate that assessments of population dynamics and life history attributes of a species should not be restricted to a single site.

Acknowledgements. I am grateful to my supervisor, Dr A. J. Butler, for his guidance during this study and comments on early drafts of the manuscript. The field assistance and good humour of my friends G. A. Powell, J. M. Davis, A. D. T. Bennett, and $\mathrm{H}$. Chernoff was most welcome. Early drafts of this manuscript were improved by M. C. Cappo, P. G. Fairweather and D. C. Paton. I also thank R. Evans for producing the figures and 2 anonymous reviewers for their comments. $P$. Kott kindly confirmed the identity of the 2 ascidian populations. Financial support was provided by the Ecological Society of Australia, the Victorian Institute of Marine Science and a University of Adelaide Postgraduate Research Award. This report is a contribution from the University of Adelaide, Coobowie Marine Research Station.

\section{LITERATURE CITED}

Andrewartha, H. G., Birch, L. C. (1954). The distribution and abundance of animals. University of Chicago Press, Chicago

Andrewartha, H. G., Birch, L. C. (1984). The ecological web: more on the distribution and abundance of animals. University of Chicago Press. Chicago

Bak, R. P. M. Sybesma, J., van Duyl, F. C. (1981). The ecology 
of the tropical compound ascidian Trididemnum solidum. II. Abundance, growth and survival. Mar Ecol. Prog. Ser. 6: $43-52$

Charnov, E. L., Schaffer, W M. (1973). Life history consequences of natural selection: Coles result revisited. Am. Nat. 107: 791-793

Chesson, P. L. (1978). Predator-prey theory and variability. Ann. Rev. Ecol. Syst. 9: 323-347

Chesson, P. L. (1985). Environmental variation and the coexistance of species. In: Diamond, J., Case, T J. (eds.) Community ecology. Harper \& Row, New York, p. 240-256

Connell, J. H., Sousa, W. P. (1983). On the evidence needed to judge ecological stability. Am. Nat. 121: 789-824

Davis, A. R. (1987). Variation in recruitment of the subtidal colonial ascidian Podoclavella cylindrica (Quoy and Gaimard): the role of substratum choice and early survival. J. exp. mar. Biol. Ecol. 106: 57-71

Davis, A. R. (1988). Effects of variation in initial settlement on distribution and abundance of Podoclavella moluccensis Sluiter J. exp. mar. Biol. Ecol. 117: 157-165

den Boer, P. J. (1968). Sreading of risk and stabilization of animal numbers. Acta Biotheor. 18: 165-194

Elton, C. (1930). Animal ecology and evolution. Clarendon, Oxford

Engelman, L. (1985). One-way analysis of variance and covariance. In: Dixon W. J. (chief ed.) BMDP statistical software. University of California Press, Berkeley, p. $347-358$

Frank, P. W. (1968). Life histories and community stability. Ecology 49: 355-357

Goodbody, I. (1961). Continuous breeding in three species of tropical ascidians. Proc. zool. Soc. Lond. 136: 403-409

Harper, J. L. (1977). Population biology of plants. Academic Press, London

Heyward, A. J., Stoddart, J. A. (1985). Genetic structure of two species of Montipora on a patch reef: conflicting results from electrophoresis and histocompatibility. Mar. Biol. 85: $117-121$

Highsmith, R. C. (1982). Reproduction by fragmentation in corals. Mar Ecol. Prog. Ser 7: 207-226

Hughes, T P., Jackson, J. B. C. (1980). Do corals lie about their age? Some demographic consequences of partial mortality, fission and fusion. Science 109: 713-715

Hughes, T P., Jackson, J. B. C. (1985). Population dynamics and life histories of foliaceous corals. Ecol. Monogr. 55: $141-166$

Huitema, B. E. (1980). The analysis of covariance and alternatives. Wiley $\&$ Sons, New York

Jackson, J. B. C. (1985). Distribution and ecology of clonal and aclonal benthic invertebrates. In: Jackson, J. B. C., Buss, L. W., Cook, R. E. (eds.) Population biology and evolution of clonal organisms. Yale University Press, New Haven, p. 297-357

Karlson, R. H. (1983). Disturbance and monopolization of a spatial resource by Zoanthus sociatus (Coelenterata, Anthazoa). Bull. mar Sci. 33: 118-131

Kay, A. M., Butler, A. J. (1983). 'Stability' of the fouling communities on the pilings of two piers in South Australia. Oecologia (Berl.) 56: 58-66
Kay, A. M., Keough, M. J. (1981). Occupation of patches in the epifaunal communities on pier pilings and the bivalve Pinna bicolor at Edithburgh, South Australia. Oecologia (Berl.) 48: 123-130

Keough, M. J. (1984). Dynamics of the epifauna of the bivalve Pinna bicolor: interactions among recruitment, predation, and competition. Ecology 65:677-688

McFadden, C. S. (1986). Colony fission increases particle capture rates of a soft coral: advantages of being a small colony. J. exp. mar. Biol. Ecol. 103: 1-20

May, R. M. (1986). The search for patterns in the balance of nature: advance and retreats. Ecology 67; 1115-1127

Millar, R. H. (1971). The biology of ascidians. Adv. mar. Biol. 9: $1-100$

Osman, R. W. (1977). The establishment and development of a marine epifaunal community. Ecol. Monogr 47: 37-63

Russ, G. R. (1980). Effects of predation by fishes, competition, and structural complexity of the substratum on the establishment of a marine epifaunal community. J. exp. mar. Biol. Ecol. 42: 55-69

Ryland, J. S., Wigley, R. A., Muirhead, A. (1984). Ecology and colonial dynamics of some Pacific reef flat Didemnidae (Ascidiacea). Zool. J. Linn. Soc. 80: 261-282

Snedecor, G. W., Cochran, W. G. (1980). Statistical methods, 7 th edn. Iowa State University Press, Iowa

Sokal, R. R., Rohlf, F. J. (1981). Biometry, 2nd edn. W. H. Freeman and Co., San Francisco

Stearns, S. C. (1976). Life history tactics: a review of the ideas. Q. Rev. Biol. 51: 3-47

Stocker, L. J., Bergquist, P. R. (1986). Seasonal cycles, extrinsic factors and the variable effects of turfing algae on the abundance of a colonial ascidian. J. exp. mar. Biol. Ecol. 102: 1-21

Sutherland, J. P. (1981). The fouling community at Beaufort, North Carolina: a study in stability. Am. Nat. 118: 499-519

Sutherland, J. P., Karlson, R. H. (1977). Development and stability of the fouling community at Beaufort, North Carolina. Ecol. Monogr. 47: 425-446

Svane, I. (1983). Ascidian reproductive patterns related to long-term population dynamics. Sarsia 68: 249-255

Svane, I. (1984). Observations on the long-term population dynamics of the perennial ascidian, Ascidia mentula O. F. Müller, on the Swedish west coast. Biol. Bull. mar. biol. Lab., Woods Hole 167: 630-646

Svane, I., Lundalv, T (1981). Reproductive patterns and population dynamics of Ascidia mentula O.F. Müller on the Swedish west coast. J. exp. mar. Biol. Ecol. 50: 163-182

Svane, I., Lundalv, T (1982a). Population dynamics and reproductive patterns of Boltenia echinata (Ascidiacea) on the Swedish west coast. J. Neth. Sea Res. 16: 105-118

Svane, I., Lundalv, T. (1982b). Persistence stability in ascidian populations: long-term population dynamics and reproductive pattern of Pyura tessellata (Forbes) in Gullmarsfjorden on the Swedish west coast. Sarsia 67: 249-257

Tunnicliffe, V. J. (1981). Breakage and propagation of the stony coral, Acropora cervicornis. Proc. natn. Acad. Sci. U.S.A. 78: $2427-2431$

Underwood, A. J. (1981). Techniques of analysis of variance in experimental marine biology and ecology. Oceanogr. mar Biol. A. Rev. 19: 513-605 